\title{
Faktor-Faktor Penentu Eksistensi Penjual Pinang di Kabupaten Manokwari (Studi Kasus Distrik Manokwari Barat)
}

\author{
Mus Mualim, Maria M. Semet \\ Dosen Fakultas Ekonomi Dan Bisnis, Universitas Papua, \\ Permalink/DOI: http://dx.doi.org/10.32830/jfres.v1i1.1017.g765
}

Received: May 2018; Accepted: August 2018; Published: September 2018

\begin{abstract}
Abstrak
Penelitian ini berusaha menganalisis hubungan kausalitas antara sejumlah faktor yang diduga menjadi penentu eksistensi penjual pinang di Distrik Manokwari Barat. Faktor-faktor tersebut adalah tarikan pendapatan, tekanan lapangan kerja, dan faktor keluarga. ketiga faktor ini juga merupakan komponen internal yang melekat pada profil penjual pinang di Distrik Manokwari Barat. Responden penelitian ini berjumlah 96 orang penjual pinang di Manokwari. Menggunakan analisis regresi linear berganda, hasil penelitian ini menunjukkan bahwa faktor yang paling besar menentukan eksistensi penjual pinang di Kabupaten Manokwari adalah faktor keluarga. Hal ini menggambarkan bahwa pilihan penjual pinang untuk tetap bertahan di usaha kecil berjualan pinang di Manokwari lebih dominan disebabkan faktor keluarga
\end{abstract}

Kata kunci: eksistensi, tarikan pendapatan, lapangan kerja, faktor keluarga, penjual pinang

\begin{abstract}
This study attempted to analyze the causal relationship between a number of factors that were thought to be determinants of the existence of betel sellers in the West Manokwari District. These factors are the attraction of income, employment pressure, and family factors. these three factors are also internal components that are inherent in the profile of pinang sellers in West Manokwari District. Respondents of this study amounted to 96 people selling betel nut in Manokwari.Using multiple linear regression analysis, the results of this study indicate that the biggest factor determining the existence of areca nut seller in Manokwari Regency is a family factor. This illustrates that the choice of betel sellers to stay in small businesses selling betel nuts in Manokwari is more dominant due to family factors.
\end{abstract}

Keywords: existence, income pulling, job opportunity, family factor, betelnut traders

How to Cite: Mualim, M., Semet, M.M. (2018). Faktor-Faktor Penentu Eksistensi Penjual Pinang di Kabupaten Manokwari (Studi Kasus Distrik Manokwari Barat). JFRES: Journal of Fiscal and Regional Economy Studies, 1 (1), 26-34. doi:http://dx.doi.org/10.32830/jfres.v1i1.1017.g765 


\section{PENDAHULUAN}

Indonesia merupakan negara agraris, dimana pertanian memegang peran penting dari keseluruhan perekonomian nasional. Hal ini dapat ditunjukkan dari banyaknya jumlah penduduk atau tenaga kerja yang bekerja di sektor pertanian. Hal ini dapat dilihat juga dari jumlah penduduk dan tenaga kerja yang hidup dan bergantung pada sektor pertanian sehingga sektor ini masih dianggap sebagai sektor yang mampu menyerap tenaga kerja sangat besar dan merupakan mata pencaharian dominan dari masyarakat Indonesia (Thamrin, 2012).

Berhasilnya suatu kegiatan usaha tani ditentukan oleh manajemen yang baik, dimana faktor alam, sarana produksi yang merupakan rangkaian dari modal dan tenaga kerja yang digunakan dalam pelaksanaan usaha tani sangat menentukan hasil yang diperoleh. Maka usaha tani yang baik merupakan proses kegiatan usaha yang memiliki struktur yang dinamis dan mantap melalui manajemen yang teratur pula (Thamrin, 2012).

Salah satu jenis komoditi yang cukup banyak diusahakan oleh masyarakat di Indonesia Barat adalah pinang. Selain untuk konsumsi lokal, hasil tanaman ini juga telah banyak diekspor sehingga turut berperan menambah devisa negara. Tanaman pinang adalah keluarga palma yang sudah cukup lama dikenal di Indonesia. Terutama di daerah dataran rendah dan daerah daerah pantai. Penyebaran tanaman ini meliputi India sampai Kepulauan Solomon (Withmore, 1973).

Tanaman pinang memiliki banyak manfaat dalam kehidupan manusia, daunnya dapat mengobati ganguan radang tenggorokan karana mengandung minyak asiri dan juga dapat digunakan sebagai atap rumah, pelepah pinang dapat digunakan sebagai bahan baku pembungkus makanan, seperti pembungkus gula merah, batangya dapat digunakan sebagai bahan bangunan, sabut buah dapat dijadikan sebagai bahan baku pembuat kuas, bijinya dapat dijadikan sebagai bahan makanan, pewarna kain, juga sebagai obat perut kembung, tidak nafsu makan, bau mulut, gigi dan gusi dan cacingan. Dalam beberapa tahun terakhir ini, permintaan pinang di pasar internasional bukan lagi sebagai bahan makanan saja, tetapi juga sebagai bahan baku berbagai industri seperti bahan pengawet, pewarna pakaian, bahan baku kosmetik, sebagai obat-obatan dan juga dijadikan sebagai tanaman hias.

Secara empiris, biji pinang dapat mengatasi berbagai jenis penyakit, berbagai manfaat yang diperoleh dari pemanfaatan biji pinang antara lain (i) sebagai kebutuhan pokok, sumber energi dan untuk upacara adat, (ii) sebagai pengganti rokok, mengatur pencernaan dan mencegah ngantuk, (iii) sebagai bahan kosmetik dan pelangsing, (iv) sebagai bahan baku obat, dan (v) sebagai anti depresi.

Di kalangan bangsawan Melayu (baik yang terdapat di Sumatra maupun Malaka) tradisi mengunyah pinang ini dipakai sebagai jamuan ritual atau bagi para tamu atau ketika mereka bertemu. Istilah 'sekapur sirih' yang bermakna pembuka muncul dari sini. Sementara itu mengunyah pinang mempunyai fungsi yang menyangkut tata pergaulan dan tata nilai di masyarakat. Hal ini terlihat dari kebiasaan manyajikan sirih pinang untuk menjamu tamu. Ketika tamu tiba, sirih pinanglah yang disajikan sebagai hidangan pembuka, baru kemudian disusul dengan minuman kopi atau teh. Oleh karena itu masih ada kalangan yang mempunyai cara 'menginang bersama' atau sarana penghantar bicara untuk mempererat persaudaraan dan juga untuk menghargai tamu kehormatan (Wilujeng, 2012)

Saat ini di Sumatera, Jawa, Kalimantan, Sulawesi, dan Maluku kebiasaan makan pinang ini hanya terdapat pada orang tua saja. Bahkan jumlahnya semakin sedikit. Namun di Papua, kebiasaan mengunyah pinang ini melanda semua lapisan masyarakat, tua-muda, laki-laki atau perempuan. Oleh karena itu siswa-siswa dilarang mengunyah pinang di sekolah karena mengunyah pinang sama saja dengan merokok (Wilujeng, 2012)

Di Papua dan Maluku, pinang (areca catechu) termasuk jenis tanaman khas, baik karena penyebarannya yang hampir merata di seluruh wilayah, juga kegunaannya sebagai ramuan sirih pinang yang telah memasyarakat. Tanaman pinang merupakan komoditi tradisional yang 
mempunyai nilai ekonomi cukup tinggi di masyarakat konsumennya. Pinang umumnya ditanam oleh masyarakat secara khusus di kawasan pesisir sebagai tanaman pekarangan. Bagi masyarakat yang sering memanfaatkannya, pinang dikenal sebagai stimulan yang dicampur dengan sirih dan kapur atau terkadang dicampur tembakau. Tetapi bagi mereka yang peternak walaupun belum dikenal secara luas, pinang sangat besar khasiatnya karena kandungan zat kimianya yang dapat digunakan untuk mangobati ternak yang sakit (Husain, 2015).

Rumah tangga keluarga merupakan salah satu pelaku ekonomi yang berkaitan langsung dengan kegiatan ekonomi yang meliputi kegiatan produksi, distribusi, maupun konsumsi yang tujuannya untuk memenuhi kebutuhan keluarga. Rumah tangga keluarga sebagai pemilik faktor produksi, diantaranya tenaga kerja, keahlian dan modal, harus melakukan kegiatan usaha untuk memperoleh pendapatan atau penghasilan dari usaha tersebut dalam bentuk uang (Samuelson, 1992).

Salah satu bidang usaha yang bisa dilakukan oleh keluarga adalah usaha jualan pinang. Pinang merupakan makanan khas orang Papua yang dapat dikonsumsi setiap hari dan dalam acara-acara adat tertentu. Bahkan bukan hanya orang Papua saja yang mengkonsumsi pinang melainkan juga non Papua. Banyak orang Papua dan non Papua yang mengkonsumsi pinang, tetapi yang paling banyak mengkonsumsi pinang adalah orang Papua, dan pinang yang dikonsumsi adalah pinang buah dan pinang kering (Dahlan, 2001).

Usaha berjualan pinang ini merupakan salah satu usaha kecil yang dapat diusahakan oleh penduduk Papua untuk memenuhi kebutuhan ekonomi keluarga, sebagai sumber pendapatan bagi keluarga dan sebagai bahan untuk acaraacara adat atau ritual-ritual tertentu karena sudah menjadi tradisi turun-temurun bagi masyarakat yang berada di Papua sehingga masyarakat akan selalu membudidayakan pinang atau menanam pinang untuk memenuhi kebutuhannya dan mengkonsumsinya.

Pelaku penjualan pinang di Kabupaten Manokwari cukup banyak, ini dilihat dari banyaknya pondok-pondok jualan pinang di pinggir jalan maupun di pasar sentral yaitu Pasar Sanggeng, Pasar Wosi dan Pasar Borobudur. Adapun pinang yang dijual adalah pinang buah dan pinang kering. Pinang buah adalah pinang yang diambil langsung dari pohon yang ditanam sendiri dan dijual, sedangkan pinang kering adalah pinang yang diambil dari pohon kemudian dikupas dan bijinya diiris tipis dan diawetkan dengan bahan kimia secukupnya kemudian dijemur sampai kering lalu dijual. Kedua jenis pinang tersebut tidak hanya diambil dari pohon sendiri tetapi bisa dibeli di pasar sentral lalu dijual kembali.

Salah satu daerah di Manokwari yang terdapat penjual pinang adalah Distrik Manokwari Barat. Dimana di sepanjang jalan terdapat pondokpondok jualan pinang yang berada di wilayah tersebut. Setiap usaha termasuk usaha penjual pinang untuk membuka usahanya yang paling dibutuhkan adalah modal usaha, maka usaha penjualan pinang yang berada di Distrik Manokwari Barat menggunakan modal awal yang berasal dari modal pribadi atau sendiri dan juga modal dari luar atau pinjaman. Dengan demikian maka penjual pinang akan terus menjual pinang walaupun dalam keadaan krisis ekonomi.

Usaha penjualan pinang di Manokwari dapat dikatakan terus mengalami peningkatan. Hal ini dapat terlihat dari semakin banyaknya lapak dan pondok-pondok penjual pinang baru yang tumbuh di kota Manokwari khususnya di wilayah Distrik Manokwari Barat. Fenomena ini boleh jadi dipicu oleh semakin sempitnya lapangan pekerjaan, di saat bersamaan pemerintah telah menerapkan moratorium penerimaan CPNS yang menjadikan pilihan-pilihan pekerjaan semakin sedikit. Dalam kondisi demikian, berjualan pinang dapat menjadi solusi untuk tetap bertahan dan mendapatkan pendapatan sambil mencari pekerjaan yang diharapkan.

Selain faktor sempitnya lapangan pekerjaan, tradisi berjualan pinang harus diakui juga dilakukan turun-temurun dalam keluarga sehingga jumlah penjual pinang cenderung bertahan dan bahkan mengalami peningkatan. Meskipun pemerintah daerah berusaha untuk menertibkan sejumlah lokasi penjual pinang yang dipandang kurang tepat dengan tata kota, namun fakta di 
lapangan justru keberadaan para penjual pinang ini semakin banyak pada lokasi-lokasi baru. Ada banyak dugaan mengapa eksistensi penjual pinang di Manokwari cukup handal, baik faktor budaya, ekonomi dan sosial, sehingga fenomena ini layak untuk diteliti lebih lanjut.

Berangkat dari latar belakang yang telah dipaparkan di atas, maka dirasa perlu untuk meneliti tentang faktor-faktor apa saja yang menjadi penentu bertahannya penjual pinang di Distrik Manokwari Barat serta faktor apa yang paling dominan menentukan bertahannya penjual pinang di Distrik Manokwari Barat.

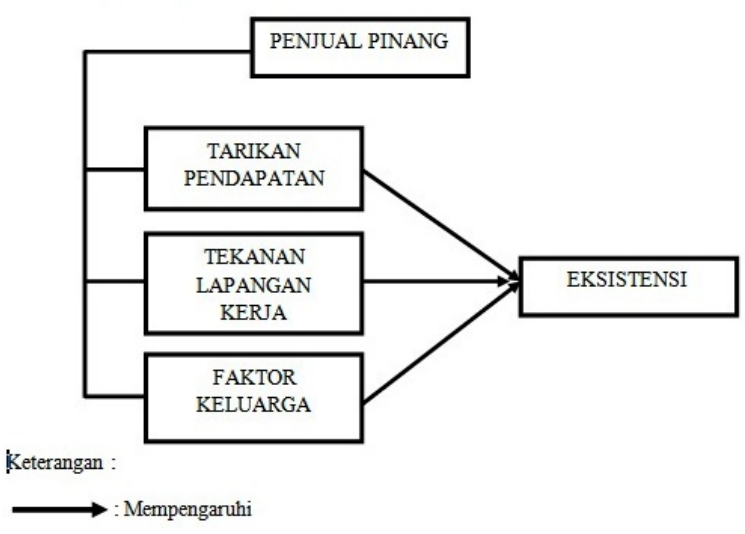

Gambar 1. Kerangka pikir penelitian

\section{$\underline{\text { Eksistensi }}$}

Menurut kamus besar Bahasa Indonesia, Eksistensi adalah keberadaan, kehadiran yang mengandung unsur bertahan. Sedangkan menurut Abidin (2007) eksistensi adalah suatu proses yang dinamis, suatu, menjadi atau mengada. Ini sesuai dengan asal kata eksistensi itu sendiri, yakni exsistere, yang artinya keluar dari, melampaui atau mengatasi. Jadi eksistensi tidak bersifat kaku dan terhenti, melainkan lentur atau kenyal dan mengalami perkembangan atau sebaliknya kemunduran, tergantung pada kemampuan dalam mengaktualisasikan potensi-potensinya.

Eksistensi bukanlah suatu yang sudah selesai, tapi suatu proses terus-menerus melalui 3 (tiga) tahap, yaitu: dari tahap eksistensi estetis kemudian ke tahap etis, dan selanjutnya melakukan lompatan ke tahap eksistensi religius sebagai tujuan akhir. Menurut Satoto (2007) dalam (Sinaga (2011) sampai saat kini tidak ada satupun tulisan ilmiah bidang hukum, baik berupa buku, disertasi maupun karya ilmiah lainnya yang membahas secara khusus pengertian eksistensi. Pengertian eksistensi selalu dihubungkan dengan kedudukan dan fungsi hukum atau fungsi suatu lembaga hukum tertentu. Basah (2009) dalam (Sinaga 2011) mengemukakan pengertian eksistensi dihubungkan dengan kedudukan, fungsi, kekuasaan atau wewenang pengadilan dalam lingkungan pada peradilan administrasi di Indonesia (Sinaga, 2011).

\section{Usaha Penjual Pinang}

Usaha adalah kegiatan manusia dengan menggerakkan tenaga dan pikiran untuk mencapai suatu tujuan yang mengarah pada kebutuhan hidup (Dahlan, 2001). Penjualan adalah ilmu dan seni yang mempengaruhi pribadi yang dilakukan oleh penjual pada umumnya untuk mengajak orang lain agar bersedia membeli barang dan jasa yang ditawarkan. Penjual sangat penting dalam mekanisme pasar karena dapat menciptakan suatu proses pertukaran barang dan jasa antar penjual dan pembeli (Basu, 1993). Usaha penjualan pinang dapat diartikan sebagai usaha yang dilakukan oleh masyarakat untuk memperoleh tambahan pendapatan guna memenuhi kebutuhan hidupnya.

\section{Pinang}

Pinang adalah sejenis palma yang tumbuh di daerah-daerah Pasifik, Asia dan Afrika bagian timur. Pinang juga merupakan nama buahnya yang diperdagangkan orang. Ada berbagai nama daerah diantaranya adalah pineung (Aceh), pining (Batak Toba), penang (Madura), jambe (Sunda, Jawa), bua, ua, wua, pua, fua, hua (aneka bahasa di Nusa Tenggara dan Maluku) dan berbagai sebutan lainya. Dalam bahasa Inggris dikenal sebagai betel palm atau betel nut tree, dan nama ilmiahnya adalah areca catechu L.

Tanaman pinang (araca catechu L) di Indonesia sejak dulu telah banyak dimanfaatkan oleh masyarakat khususnya buah, yang digunakan untuk campuran makan sirih. Tanaman pinang mudah tumbuh di Indonesia, biasanya ditanam di pekarangan rumah, taman atau tumbuh di pinggir sungai dengan bentuknya yang indah. Biji pinang disebut dengan betel nut dan ditanam 
secara luas di India, Srilangka sampai ke China dan Philipina, di Malaysia dan Indonesia juga diperoleh di Afrika sebelah timur (Tanzania).

\section{Tarikan Pendapatan}

Adapun beberapa definisi pendapatan menurut Badan Pusat Statistik sesuai dengan konsep dan definisi (1999), pendapatan keluarga adalah seluruh pendapatan dan penerimaan yang diterima oleh Anggota Rumah Tangga Ekonomi (ARTE). Sedangkan menurut Sumardi dan Evers (1984), menyebutkan bahwa pendapatan rumah tangga merupakan jumlah keseluruhan dari pendapatan formal, informal dan pendapatan subsistem.

Tetap bertahannya penjual pinang di Manokwari (khususnya Distrik Manokwari Barat) boleh jadi karena faktor tarikan pendapatan. Artinya, besarnya pendapatan yang dapat diraup menjadi peluang bagi para penjual pinang sehingga memilih bertahan dengan profesi dan aktivitasnya sebagai penjual pinang.

\section{Tekanan Lapangan Pekerjaan}

Pengangguran merupakan masalah yang sangat kompleks karena mempengaruhi sekaligus dipengaruhi oleh beberapa faktor yang saling berinteraksi mengikuti pola yang tidak selalu mudah untuk dipahami dan sampai saat ini belum bisa untuk diatasi oleh pemerintah nasional pada umumnya dan pemerintah daerah pada khususnya. Tingginya angka pengangguran mempunyai implikasi sosial yang luas, karena mereka yang tidak bekerja berarti tidak mempunyai penghasilan (Samir, 2015).

Hilangnya sumber penghasilan membuka peluang penduduk mengalami kesulitan untuk memenuhi kebutuhan pokok, yang pada akhirnya mampu membawa mereka kedalam jurang kemiskinan. Persoalannya semakin rumit karena semakin tinggi angka pengangguran terbuka maka semakin besar potensi kerawanan sosial yang mungkin ditimbulkannya, contohnya kriminal, gejolak sosial, politik, kemiskinan dan pemborosan yang luar biasa (Samir, 2015).

\section{Faktor Keluarga}

Tradisi mengonsumsi pinang oleh masyarakat Papua telah berjalan turun-temurun dan diwaris- kan dari generasi ke generasi, karena bermanfaat dan memiliki fungsi sosial dalam masyarakat maka eksistensinya bertahan hingga kini. Dalam pemikiran dan keyakinan penduduk asli Papua, semua bagian dari pohon pinang memiliki manfaat, (misalnya untuk mengobati luka kulit, menguatkan gigi dan gusi, obat cacingan dan lainnya). Maka pohon pinang dengan semua bagiannya menjadi penting dalam keseharian hidup. Karena fungsi, manfaat beserta maknanya maka objek material ini menjadi bernilai dalam sektor ekonomi, sisi sosial-budaya, maupun sisi medis bagi kelangsungan hidup manusia (Nugroho, 2016).

Oleh karena itu maka tradisi dan adat-istiadat mengonsumsi pinang dan membudidayakannya di kalangan masyarakat Papua yang selalu membawa nilai-nilai ekonomis dari pinang tersebut. Berdasarkan tradisi dari nenek moyangnya dulu untuk menjual pinang akan diikuti oleh generasi-generasi berikutnya untuk membudidayakan pinang, mengonsumsinya dan menjualnya untuk kelangsungan hidup.

\section{METODE PENELITIAN}

Penelitian ini berusaha menganalisis hubungan kausalitas antara sejumlah faktor yang diduga menjadi penentu eksistensi penjual pinang di Distrik Manokwari Barat. Faktor-faktor tersebut adalah tarikan pendapatan, tekanan lapangan kerja, dan faktor keluarga. ketiga faktor ini juga merupakan komponen internal yang melekat pada profil penjual pinang di Distrik Manokwari Barat. Artinya, para penjual pinang dalam penelitian ini adalah mereka yang profilnya adalah belum memiliki pekerjaan tetap, berpendapatan dibawah upah minimum provinsi (UMP) atau tidak tetap, dan secara historis memiliki sejarah sebagai penjual pinang secara turun-temurun.

Penelitian ini dilaksanakan di Distrik Manokwari Barat, Kabupaten Manokwari. Subjek dalam penelitian ini adalah orang yang melakukan usaha penjualan pinang di Distrik Manokwai Barat, yang menjadi objek dalam penelitian ini adalah Tarikan Pendapatan, Tekanan Lapangan Kerja, Faktor Keluarga para penjual pinang di Distrik Manokwari Barat, Kabupaten Manokwari. 
Karena penelitian ini untuk mengetahui hubungan yang bersifat mempengaruhi antara dua variabel atau lebih maka penelitian ini mengunakan desain penelitian atau asosiatif dan menurut sifat hubunganya penelitian menggunakan sebab-akibat (kausal). Menurut Sugiyono (2007), desain kausal adalah penelitian yang bertujuan menganalisis hubungan sebab-akibat antara veriabel bebas dan variabel independen (variabel yang mempengaruhi) dan variabel dependen (variabel yang dipengaruhi).

Sumber data yang digunakan dalam penelitian ini adalah data primer dan data sekunder. Data primer dalam penelitian didapat secara langsung dari objek penelitian yaitu para penjual pinang di Distrik Manokwari Barat. Sedangkan data sekunder diperoleh dari jurnal dan buku yang berhubungan dengan penelitian ini.

Teknik pengumpulan data primer yang digunakan dalam penelitian ini adalah wawancara. Dalam penelitian ini peneliti mengunakan metode pendekatan wawancara terstruktur, yaitu dimana pihak wawancara sebelum melakukan wawancara terlebih dahulu mempersiapkan daftar pertanyaan, atau daftar isian (kuesioner) untuk dibacakan pada saat dilakukan wawancara dengan responden (Teguh, 2005). Metode ini digunakan untuk mengumpulkan data tentang gambaran eksistensi penjual pinang, melalui beberapa variabel pengukuran. Pengukuran dalam kuesioner menggunakan skala likert.

Analisis regresi linear berganda digunakan untuk mengukur pengaruh variabel independen terhadap variabel dependen. Adapun variabel yang diregresikan dalam penelitian ini yaitu Tarikan Pendapatan $\left(\mathrm{X}_{1}\right)$, Tekanan Lapangan Pekerjaan $\left(\mathrm{X}_{2}\right)$, Faktor Keluarga $\left(\mathrm{X}_{3}\right)$, dan Eksistensi (Y). Untuk model persamaan regresinya adalah sebagai berikut:

$\mathrm{Y}=\mathrm{a}+\mathrm{b}_{1} \mathrm{X}_{1}+\mathrm{b}_{2} \mathrm{X}_{2}+\mathrm{b}_{3} \mathrm{X}_{3}+\mathrm{e}$

Kererangan:

Y : Eksistensi

$\mathrm{X}_{1} \quad$ : Tarikan Pendapatan

$\mathrm{X}_{2} \quad$ : Tekanan Lapangan Pekerjaan

$\mathrm{X}_{3} \quad$ : Faktor Keluarga $\mathrm{b}_{1}, \mathrm{~b}_{2}, \mathrm{~b}_{3} \quad$ : Koefisien regresi

e : Standar error

\section{HASIL DAN PEMBAHASAN}

\section{Identitas responden}

Responden dalam penelitian ini adalah penjual pinang yang melakukan kegiatan ekonomi di Distrik Manokwari Barat Kabupatan Manokwari sebanyak 96 orang. Berdasarkan usia, sebaran responden dapat dilihat pada Tabel 1.

Data pada Tabel 1. menunjukkan bahwa terdapat 9 penjual pinang dengan persentase $9 \%$ berada pada kelompok usia lebih dari 55 tahun dan 87 penjual pinang dengan persentase $91 \%$ berada pada kelompok usia 15-55 yang berarti usia ini masuk dalam kelompok usia produktif, dimana menurut Soeharjo dan Patong (1991) adalah sangat baik karena pada umumnya tenaga kerja yang berumur muda (umur produktif) relatif mempunyai kemampuan fisik yang lebih besar serta mudah menerima dan menerapkan inovasi. Banyaknya penjual pinang yang berada pada usia produktif juga menjadi indikasi bahwa berjualan pinang bukan lagi pekerjaan yang identik dengan kalangan lanjut usia namun sudah familiar bagi generasi muda.

Tabel 1. Sebaran responden berdasarkan usia

\begin{tabular}{ccc}
\hline Umur & $\begin{array}{c}\text { Jumlah Responden } \\
\text { (jiwa) }\end{array}$ & Nisbah (\%) \\
\hline$<15$ & - & - \\
$15-55$ & 87 & 91 \\
$>55$ & 9 & 9 \\
\hline Total & $\mathbf{9 6}$ & $\mathbf{1 0 0}$ \\
\hline Sumber: Data primer (diolah), 2017
\end{tabular}

Selanjutnya berdasarkan jenis kelamin, sebaran responden penelitian ini adalah seperti pada Tabel 2.

Tabel 2. Sebaran responden berdasarkan jenis kelamin

\begin{tabular}{ccc}
\hline Jenis kelamin & Jumlah (jiwa) & Nisbah (\%) \\
\hline Laki-laki & 4 & 4 \\
Perempuan & 92 & 96 \\
\hline Total & $\mathbf{9 6}$ & $\mathbf{1 0 0}$ \\
\hline
\end{tabular}

Sumber: Data primer (diolah), 2017 
Tabel 2 menunjukkan bahwa mayoritas penjual pinang di Distrik Manokwari Barat berjenis kelamin perempuan (96\%). Dalam dunia pemasaran, perempuan memang memiliki kemampuan (skill) yang lebih baik dibandingkan lakilaki. Selain memiliki tingkat kesabaran dan ketekunan yang lebih baik dibandingkan lakilaki, perempuan lebih bisa menarik calon pembeli untuk membeli produk yang dijual. Dalam penelitian ini, harus diakui bahwa persepsi publik secara umum juga mengidentikan profil penjual pinang umumnya dari kalangan perempuan.

Sementara itu, berdasarkan alamat lokasi usaha berjualan pinang, responden penelitian ini dibagi dalam tiga lokasi dengan perinciannya seperti disajikan pada Tabel 3. Pada Tabel 3 di atas menunjukkan bahwa penjual pinang di Distrik Manokwari Barat yang paling banyak berada di Kelurahan Amban sebanyak 53 penjual pinang, dan yang berikutnya adalah Kelurahan Padarni sebanyak 24 penjual pinang sedangkan yang paling sedikit penjual pinang adalah di Kelurahan Sanggeng sebanyak 19 penjual pinang. Kelurahan Amban menjadi kelurahan dengan jumlah penjual pinang terbanyak memberi gambaran bahwa konsumen buah pinang kini telah bergeser dari kalangan generasi tua ke generasi muda. Hal ini terjadi karena Kelurahan Amban identik dengan penduduk yang didominasi oleh mahasiswa dan penduduk usia produktif.

Tabel 3. Sebaran responden berdasarkan alamat lokasi berjualan

\begin{tabular}{clcc}
\hline No & Kelurahan & Jumlah & Nisbah (\%) \\
\hline 1 & Amban & 53 & 55 \\
2 & Sanggeng & 19 & 20 \\
3 & Padarni & 24 & 25 \\
\hline & Total & $\mathbf{9 6}$ & $\mathbf{1 0 0}$ \\
\hline
\end{tabular}

Sumber: Data primer (diolah), 2017

Dari hasil estimasi regresi di atas dapat diketahui bahwa nilai koefisien regresi $\mathrm{X}_{1}$ adalah 0,247006, $\mathrm{X}_{2}$ adalah 0,044111 dan $\mathrm{X}_{3}$ adalah 1,042234 sedangkan koefisien regresi $\mathrm{Y}$ adalah 1.244682. Selanjutnya untuk nilai R-squared $\left(\mathrm{R}^{2}\right)$ adalah 0.288488, Adjusted R-squared adalah 0,265287 . Jika dituliskan dalam persamaan regresi adalah:
Eksistensi $=1 \cdot 244682+0,2470_{\text {Tarikan Pendapatan }}+$

$0,0441_{\text {Tekanan Lapangan Pekerjaan }}+$

1,0422 Faktor Keluarga

Sesuai hasil estimasi regresi di atas, maka faktor yang paling besar menentukan eksistensi penjual pinang di Kabupaten Manokwari adalah faktor keluarga. Hal ini menggambarkan bahwa pilihan penjual pinang untuk tetap bertahan di usaha kecil berjualan pinang di Manokwari lebih dominan disebabkan faktor keluarga. Artinya, sangat besar kemungkinan pilihan berjualan pinang karena alasan faktor aktivitas yang sudah dilakukan turun temurun.

Selanjutnya faktor tekanan lapangan pekerjaan menjadi faktor dengan pengaruh yang paling rendah terhadap eksistensi penjual pinang di Manokwari. Rendahnya pengaruh tekanan lapangan pekerjaan ini dapat dimengerti karena mayoritas penjual pinang di Manokwari berjenis kelamin perempuan dan berjualan pinang tidak jauh dari kediamannya. Psikologi perempuan yang memilih tidak pergi jauh dari rumah menjadikan berjualan pinang sebagai aktivitas yang dipilih karena dekat dengan kediaman namun tetap mendapatkan tambahan penghasilan.

Sementara nilai $\mathrm{R}^{2}$ yang hanya sebesar 0,288488 menjelaskan bahwa kemampuan model dalam menjelaskan masalah penelitian hanya sebesar 28,84\%. Ada 71,16\% pengaruh faktor lain terhadap eksistensi penjual pinang di Kabupaten Mankokwari.

Hasil pengujian probabilitas tarikan pendapatan adalah sebesar 0.313 pada tingkat kesalahan 0.05. Pada pengujian hipotesis disimpulkan bahwa nilai probabilitas tarikan lapangan pekerjaan lebih besar dibandingkan dengan taraf kesalahan, yang berarti tarikan pendapatan tidak berpengaruh sigmifikan terhadap eksistensi penjual piang di Distrik Manokwari Barat Kabupaten Manokwari. Semakin tinggi tarikan pendapatan maka semakin tinggi minat berjualan pinang. Sebaliknya semakin rendah pendapatan penjual pinang maka semakin rendah pula minat berjualan pinang.

Adapun nilai koefisien regresi tarikan pendapatan adalah sebesar 0.247 yang berarti setiap perubahan variabel tarikan pendapatan 
sebesar 1\% maka akan menambah eksistensi penjual pinang sebesar $0.247 \%$. Para penjual pinang akan selalu eksis menjual pinang karena berbagai faktor, salah satunya adalah tarikan pendapatan. Semakin besar pendapatan yang diterima dari hasil penjualan pinang maka penjual pinang akan selalu eksis menjual pinang.

Hasil pengujian probabilitas tekanan lapangan kerja adalah sebesar 0.855 pada tingkat kesalahan 0.05. Pada pengujian hipotesis disimpulkan bahwa nilai probablitas tekanan lapangan kerja lebih besar dibandingkan dengan taraf kesalahan yang berarti tekanan lapangan kerja tidak berpengaruh signifikan terhadap eksistensi penjual pinang di Distrik Manokwari Barat, Kabupaten Manokwari. Adapun nilai koefisien regresi tekanan lapangan pekerjaan adalah sebesar 0.044 yang berarti setia perubahan variabel tekanan lapangan kerja sebesar 1\% maka akan mengurangi eksistensi penjual pinang sebesar 0.044\%. Para penjual pinang akan selalu eksis menjual pinang karena berbagai faktor, salah satunya adalah tekanan lapangan keja.

Hasil pengujian probabilitas faktor keluarga adalah sebesar 0.00 pada tingkat kesalahan 0.05. pada pengujian hipotesis disimpulkan bahwa nilai probablitas faktor keluarga lebih kecil dibandingkan dengan taraf kesalahan yang berarti faktor keluarga berpengaruh signifikan terhadap eksistensi penjual pinang di Distrik Manokwari Barat, Kabupaten Manokwari. Adapun nilai koefisien regresi faktor keluarga adalah sebesar 1.042yang berarti setia perubahan variabel faktor keluarga sebesar 1\% maka akan meningkatkan eksistensi penjual pinang sebesar $1.042 \%$. Para penjual pinang akan selalu eksis menjual pinang karena berbagai faktor, salah satunya adalah faktor keluarga.

Penelitian ini hanya menganalisis tiga faktor yang diduga mempengaruhi eksistensi penjual pinang di Distrik Manokwari Barat Kabupaten Manokwari yakni tarikan pendapatan, tekanan lapangan pekerjaan dan faktor keluarga. Ada faktor-faktor lain yang juga berpengaruh seperti daerah asal, faktor harga, faktor lokasi dan lainnya. Kiranya kepada peneliti selanjutnya dapat menganalisis faktor-faktor tersebut dalam penelitian selanjutnya.

\section{KESIMPULAN}

Berdasarkan hasil penelitian yang telah dilakukan, maka peneliti dapat menarik beberapa kesimpulan sebagai berikut:

1. Faktor-faktor penentu eksistensi penjual pinang di Kabupaten Manokwari antara lain tarikan pendapatan, tekanan lapangan pekerjaan dan faktor keluarga.

2. Faktor keluarga merupakan faktor yang paling besar pengaruhnya terhadap keputusan bertahannya seorang penjual pinang di Kabupaten Mankwari. Sementara faktor yang paling kecil pengaruhnya adalah tekanan lapangan pekerjaan.

3. Sejumlah faktor lain seperti tingkat harga, daerah asal penjual pinang, serta lokasi berjualan diduga juga ikut berpengaruh terhadap eksistensi para penjual pinang di Kabupaten Manokwari. Hal ini menjadi masukan bagi peneliti berikutnya.

\section{DAFTAR PUSTAKA}

Abidin, Zainal. 2007. Analisis Eksistensial, Sebuah Pendekatan Alternatif untuk Psikologi dan Psikiatri. Raja Grafindo Persada. Jakarta.

Basu, Swastha. 1993. Pengantar Bisnis Modern, Edisi Ketiga. Liberti. Yogyakarta.

Dahlan, Siamat. 2001. Manajemen Lembaga Keuangan, Edisi Ketiga. Fakultas Ekonomi Universitas Indonesia. Jakarta.

Husain, dkk. 2015. Kesesuaian Lahan untuk Tanaman Pinang (Areca Catechu) di DAS Remu, Sorong, Papua Barat. Universitas Sam Ratulangi. Manado.

Mulyanto, Sumardi dan Hans Dieter Evers. 1985. Kemiskinan dan Kebutuhan Pokok. Rajawali. Jakarta.

Nugroho, SHP. 2014. Hubungan Aktivitas Fisik dan Kontipasi dengan Derajat Hemoroid di URJ Bedah RSUD Dr. Soegiri Lamongan. Surya. Surabaya.

Samir, Salman. 2015 Analisis Faktor-faktor yang Mempengaruhi Tingkat Pengangguran di Kabupaten Sidenreng Rappang. Universitas Hasanuddin. Makassar.

Samuelson, Paul A. dan William D. Nordhaus. 1992. Makro Ekonomi, Edisi XIV. Alih 
Bahasa: Haris Munandar. Erlangga. Jakarta. Sinaga, S. 2011. Pengaruh Substitusi Tepung Terigu dan Jenis Penstabil dalam Pembuatan Cookies Labu Kuning. (Skripsi). Universitas Sumatera Utara. Medan.

Sugiyono. 2007. Metode Penelitian Kuantitatif Kualitatif dan $R \& D$. Alfabeta. Bandung.

Thamrin, Abdullah dkk. 2012. Manajemen Pemasaran. PT. Rajagrafindo Persada. Jakarta.
Wahyono, Teguh. 2005. Sistem Informasi: Konsep Dasar, Analisis Desain dan Implementasi. Graha Ilmu. Jakarta.

Whitmore, T. C. 1975. Communities and Ecosystem. Second Edition. Mac Millan Publishing. New York.

Wilujeng, Puput. (2012). Pengaruh Konformitas pada Geng Remaja Terhadap Perilaku Agresif di SMK PGRI 7 Surabaya. Skripsi Universitas PGRI Surabaya. Surabaya. 